\title{
Sistem Pendukung Keputusan Pemilihan Bahan Bakar Sepeda Motor Matic Mengunakan Metode Simple Additive Weighting (SAW)
}

\author{
Renny Puspita Sari*, Muhammad Rizqi Darmawan \\ Fakultas Matematika Ilmu Pengetahuan Alam, Prodi Sistem Informasi, Universitas Tanjungpura, Pontianak, Indonesia \\ Email: ${ }^{1,{ }^{*}}$ rennysari.untan@gmail.com, ${ }^{2}$ muhammadrizqid12@ student.untan.ac.id \\ Submitted: 08/05/2021; Accepted: 26/05/2021; Published: 30/05/2021
}

\begin{abstract}
Abstrak-Bahan bakar minyak merupakan kebutuhan utama ketika masyarakat ingin berkendara, salah satu kendaraannya yaitu sepeda motor matic yang banyak digunakan masyarakat. Terdapat banyak bahan bakar di SPBU yaitu premium, pertalite dan pertamax. Dalam memilih bahan bakar masyarakat masih terdapat banyak yang dipertimbangkan, baik itu dari kualitas, harga, keiritan bahan bakar, dan lainnya. Dari berbagai pertimbangan itu masyarakat pasti bingung mana yang sesuai untuk kebutuhannya. Untuk itu adanya SPK(Sistem Pendukung Keputusan) pemilihan bahan bakar sepeda motor untuk membantu dalam mencari bahan bakar yang sesuai. Sistem ini dibuat dengan menggunakan metode MADM(Multiple Attribute Decision Making) untuk mencari alternatif dari berbagai kriteria yang didalamnya metode SAW(Simple Additive Weighting) untuk mencari rating dari setiap kriteria terbobot. Pada metode SAW rating terbesar merupakan hasil pilihan alternatif. Hasil perhitungan dari metode adalah apabila alternatif yang terpilih memenuhi kriteria yang telah ditentukan. Pada penelitian ini hasil dari simulasi perhitungan yang didapatkan melalui survey adalah bahan bakar pertalite dengan hasil akhir perankingan 0,718 sedangkan pertamax 0,716 dan premium 0,665 .
\end{abstract}

Kata Kunci: SPK; SPBU; Bahan Bakar; MADM; SAW

\begin{abstract}
Fuel oil is the main requirement when people want to drive, one of the vehicles is an automatic motorbike which is widely used by the community. There are many fuels at the gas station, namely premium, pertalite and pertamax. In choosing community fuels, there are still many things to consider, both in terms of quality, price, fuel efficiency, and others. From these various considerations, people must be confused about which one is suitable for their needs. For this reason, there is a DSS (Decision Support System) for selecting motorcycle fuel to assist in finding the appropriate fuel. This system was created using the MADM (Multiple Attribute Decision Making) method to find alternatives to various criteria, including the SAW (Simple Additive Weighting) method to find a rating for each weighted criterion. In the SAW method, the largest rating is the result of alternative choices. The calculation result of the method is if the selected alternative meets the predetermined criteria. In this study, the results of the calculation simulation obtained through the survey are pertalite fuel with the final rating of 0.718 , while Pertamax is 0.716 and premium is 0.665 .
\end{abstract}

Keywords: DSS; Gas Station; Fuel; MADM; SAW

\section{PENDAHULUAN}

Saat ini dalam melakukan setiap kegiatan bepergian baik dekat maupun jauh memerlukan alat transportasi kendaraan untuk menempuh perjalanan tersebut. Masyarakat sekarang banyak menggunakan kendaraan roda dua sebagai alat transportasi, yang menjadi pilihan masyarakat salah satunya yaitu sepeda motor terutama sepeda motor matic. Sepeda motor matic merupakan alat transportasi roda dua yang paling sering digunakan karena harga dari sepeda motor matic umumnya lebih murah dibandingkan kendaraan bermotor lainnya. Selain itu, sepeda motor banyak digunakan karena lebih cepat dan praktis sehingga lebih mudah dalam menjangkau tujuan yang diinginkan. Dalam penggunaannya sepeda motor merupakan alat tranportasi bermotor atau bermesin yang memerlukan bahan bakar minyak untuk menghidupkannya. Jika tidak ada bahan bakar minyak sepeda motor tidak dapat digunakan, karena bahan bakar minyak sebagai bahan untuk pembakaran dan pengapian dalam menghidupkan mesin sepeda motor.

Bahan bakar minyak sepeda motor sekarang sudah ada berbagai macam yaitu premium, pertalite dan pertamax. Karena berbagai macam jenis bahan bakar minyak untuk sepeda motor tersebut, membuat masyarakat bingung dalam memilih bahan bakar minyak mana yang cocok untuk sepeda motor miliknya. Pemilihan bahan bakar tidak boleh sembarangan terdapat beberapa aturan khusus yang mengharuskan kita untuk menyesuaikan antara rasio kompresi dengan nilai oktan suatu bahan bakar[1]. Masyarakat akan merasa rugi apabila salah memilih bahan bakar, baik dari segi kualitas dari bahan bakar minyak ataupun dari harga bahan bakar minyak tersebut. Meski begitu, masyarakat umumnya lebih banyak memilih bahan bakar minyak sepeda motor yang sering digunakan sekarang yaitu pertalite karena harganya yang tidak jauh berbeda dan mulai langkanya premium. Selain harganya, kualitas yang dimiliki pertalite juga lebih baik dibandingkan dengan premium. Sedangkan pertamax jarang digunakan karena harganya yang mahal, tetapi saat ini sudah banyak orang yang mulai beralih ke pertamax karena orang-orang malas mengantri untuk membeli pertalite ataupun premium di Stasiun Pengisian Bahan Bakar Umum (SPBU). Setiap jenis bahan bakar minyak memiliki kualitas yang berbeda jika diterapkan pada sepeda motor. Kualitas tersebut dapat berbeda dalam menghasilkan performa mesin dan dampak dari polusi yang ditimbulkan oleh bahan bakar minyak yang berbeda sesuai kandungan nilai oktan atau Research Octane Number (RON) yang dmiliki setiap bahan bakar minyak tersebut. Kualitas salah satu faktor penentu harga, biasanya semakin kualitas itu baik maka harganya pun semakin tinggi [2]. 
Di SPBU pertamina memasarkan beberapa jenis bahan bakar minyak yang mengandung Research Octane Number antara lain: premium dengan RON 88, pertalite dengan RON 90, pertamax dengan RON 92, masingmasing kandungan RON di dalam bahan bakar mempunyai spesifikasi yang berbeda-beda, semakin tinggi nilai RON, maka semakin baik dan menghasilkan polusi Nox dan Cox dalam jumlah sedikit sehingga polusi tersebut ramah lingkungan[2]. Untuk itu harga dari bahan bakar minyak tersebut berbeda-beda semakin tinggi RON yang dimiliki bahan bakar minyak tersebut maka semakin tinggi pula harga yang bahan bakar minyak tersebut. Maka dari itu, harga Pertamax selalu lebih tinggi dibandingkan dengan bahan bakar lainnya. Meski begitu, masyarakat terkadang mengabaikan kuliatas dari bahan bakar minyak, masyarakat lebih mementingkan harga yang murah dibanding kualitas. Oleh kerena itu, masyarakat jarang membeli Pertamax karena harganya yang lebih mahal. Akan tetapi, sebagian masyarakat juga tidak membeli pertalite karena antriannya yang terlalu panjang jika membelinya di Stasiun Pengisian Bahan Bakar Umum (SPBU). Sedangkan Premium, masyarakat susah untuk menemukannya karena dapat dikatakan langka, dibeberapa daerah Premium hanya dapat dibeli jika memiliki kartu subsidi dari pemerintah dan juga hanya dapat ditemukan di penjual eceran. Untuk itu masyarakat membutuhkan suatu sistem yang dapat membantu dalam memilih bahan bakar minyak sesuai dengan yang mereka butuhkan dan mereka utamakan.

Dari latar belakang masalah diatas dapat diketahui bahwa masalah dalam penelitian ini adalah tentang masyarakat bingung dalam pemilihan bahan bakar minyak yang cocok untuk kendaraan sepeda motor miliknya. Oleh kerena itu, perlu adanya Sistem Pendukung Keputusan (SPK) untuk menyelesaikan masalah ini. SPK adalah merupakan sistem bantu berbasis komputer untuk pengambilan keputusan dibidang manajemen yang bergelut dalam keputusan yang resmi terstruktur[3]. Kebutuhan sistem pendukung keputusan akan sangat diperlukan untuk menjaga kestabilan hasil akhir dari proses perhitungan pemilihan alternatif keputusan. Kerumitan dan ruang lingkup pengambilan keputusan dapat diatasi dengan Sistem Pendukung Keputusan (SPK) [4], [5]. Masyarakat dapat melihat dari berbagai macam pertimbangan atau kriteria yang dimiliki tiap bahan bakar minyak sebagai alternatif pilihan masyarakat. Kriteria yang dapat menjadi pertimbangan masyarakat yaitu kualitas dari bahan bakar minyak, keiritan bahan bakar minyak tersebut ketika digunakan, kemudian harga bahan bakar minyak tersebut dan panjang antrian ketika membeli bahan bakar minyak. Oleh karena itu, penulis membuat suatu sistem yang dapat membantu dalam pemilihan bahan bakar minyak sepeda motor. Sebelumnya telah ada penelitian mengenai pemilihan bahan bakar akan tetapi menggunakan metode AHP (Analytical Hierarchy Process) dengan judul jurnal "Penerapan Metode Analytical Hierarchy Process Dalam Memilih Bahan Bakar Minyak untuk Kendaraan Roda Dua".

Dalam penelitian ini penulis menggunakan metode Simple Additive Weighting (SAW) yang terdapat dalam metode Multiple Attribute Decision Making (MADM). Konsep dasar metode SAW adalah mencari penjumlahan terbobot dari rating kinerja pada setiap alternatif pada semua atribut[6]. Metode SAW dapat digunakan untuk mencari alternatif dengan melakukan perhitungan kriteria, dan perankingan untuk pengambilan keputusan pemilihan bahan bakar minyak. Penulis memilih menggunakan metode ini karena sistem yang dibuat memiliki sedikit alternatif sehingga lebih mudah dalam perhitungan dan dianggap lebih cepat dalam menghasilkan alternatif yang diinginkan.

\section{METODE PENELITIAN}

\subsection{Tahapan Penelitian}

Untuk menjalankan penelitian ini terdapat beberapa tahan untuk melakukannya. Tahapan yang diperlukan adalah sebagai berikut :

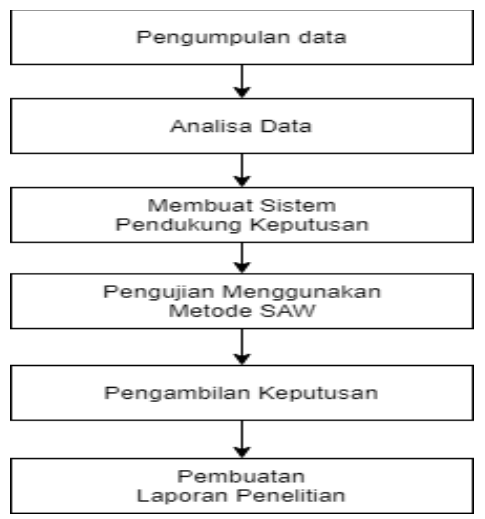

Gambar 1. Tahapan penelitian

Tahapan penelitian dimulai dengan pengumpulan data. Pengumpulan data merupakan syarat mutlak yang harus dipenuhi di dalam melakukan penelitian. Dalam usaha untuk mendapatkan data yang valid dan sesuai dengan 
yang diinginkan, maka digunakan beberapa metode pengumpulan data agar penelitian dapat dibuktikan[7]. Pengumpulan data dilakukan dengan survey menggunakan fitur google form kepada masyarakat. Kemudian data yang sudah dikumpulkan dianalisa agar dapat mengetahui kebutuhan sistem yang akan dibangun atau dikembangkan. Selanjutnya, membuat sistem pendukung keputusan dengan menggunakan metode SAW untuk menghitung kriteria dalam memilih alternatif. Setelah sistem dibuat selanjutnya melakukan pengujian perhitungan dengan metode SAW, setelah selesai pengujian didapatlah hasil alternatif pilihan yang akan digunakan untuk pengambilan keputusan. Setelah semuanya selesai hasil dari penelitian dibuat dalam bentuk laporan sebagai dokumentasi.

\subsection{Simple Additive Weighting (SAW)}

Menurut Fishburn dan MacCrimmon dalam konsep dasar metode Simple Additive Weighting (SAW) adalah mencari penjumlahan terbobot dari rating kinerja pada setiap alternatif pada semua atribut. Metode SAW memerlukan proses normalisasi matriks keputusan pada suatu skala yang akan dibandingkan dengan semua rating dari alternatif yang ada [8]. Ada beberapa langkah dalam penyelesaian metode Simple Additive Weighting (SAW) [9], sebagai berikut:

a. Menentukan kriteria-kriteria yang dijadikan acuan dalam pendukung keputusan yaitu $\mathrm{Ci}$.

b. Memberikan nilai bobot untuk masing-masing kriteria sebagai $\mathrm{W}$.

c. Menentukan rating kecocokan setiap alternatif pada setiap kriteria.

d. Membuat matriks keputusan berdasarkan kriteria (Ci).

e. Kemudian melakukan normalisasi matriks berdasarkan persamaan yang disesuaikan dengan jenis atribut (atribut keuntungan maupun atribut biaya) sehingga diperoleh matriks ternormalisasi $r$.

f. Hasil akhir diperoleh dari proses perangkingan yaitu penjumlahan dari perkalian matriks ternormalisasi $r$ dengan vector bobot sehingga diperoleh nilai terbesar yang dipilih sebagai alternatif terbaik (Ai) sebagai solusi[10].

Berikut tahapan dari proses metode SAW[11]-[14], yaitu:

1. Membentuk Matriks keputusan

$$
R=\left[\begin{array}{lll}
r_{11} & r_{21} & r_{31} \\
r_{12} & r_{22} & r_{32} \\
r_{13} & r_{23} & r_{33}
\end{array}\right]
$$

2. Melakukan Normalisasi Matrik Keputusan

Keterangan :

$$
\mathbf{r}_{\mathrm{ij}}=\left\{\begin{array}{l}
\frac{\mathrm{X}_{\mathrm{ij}}}{\operatorname{Max} \mathbf{X}_{\mathrm{ij}}} \text { Jika } \mathrm{j} \text { adalah atribut keuntungan (benefit) } \\
\frac{\operatorname{Min}_{\mathrm{ij}}}{\mathrm{X}_{\mathrm{ij}}} \text { Jika } \mathrm{j} \text { adalah atribut biaya (cost) }
\end{array}\right.
$$

$\mathrm{r}_{\mathrm{ij}} \quad=$ Rating kinerja ternormalisasi

Max = Nilai maksimum dari setiap baris dan kolom

Min = Nilai minimum dari setiap baris dan kolom

$\mathrm{X}_{\mathrm{ij}}=$ Baris dan kolom dari matriks

Dengan $r_{i j}$ adalah rating kinerja ternormalisasi dari alternatif Ai pada atribut $\mathrm{Cj} ; \mathrm{i}=1,2, \ldots \mathrm{m}$ dan $\mathrm{j}=1,2, \ldots, \mathrm{n}$.

3. Menghitung Preferensi

$$
V_{i}=\sum_{j=i}^{n} w_{j} r_{i j}
$$

Keterangan :

$\mathrm{Vi}=$ Nilai akhir dari alternatif

$\mathrm{w}_{\mathrm{j}} \quad=$ Bobot yang telah ditentukan

$\mathrm{r}_{\mathrm{ij}} \quad=$ Normalisasi matriks

Nilai yang lebih besar mengindikasikan bahwa alternatif lebih terpilih[8].

\section{HASIL DAN PEMBAHASAN}

\subsection{Penerapan Metode SAW}

Dalam pengambilan keputusan pemilihan bahan bakar sepeda motor matic perlu adanya sistem yang dapat membantu memudahkan seorang pengambil keputusan. Metode SAW ini dipilih karena metode ini menentukan nilai bobot untuk setiap atribut, kemudian dilanjutkan denga proses perankingan yang akan menyeleksi alternatif 
terbaik dari sejumlah alternatif yang ada[15]. Ada beberapa tahapan yang dilakukan dalam pemecahan masalah. Tahap pertama, menentukan alternatif yang akan dipilih oleh seorang pengambil keputusan. Alternatif tersebut adalah pertamax, pertalite dan premium. Kemudian, menentukan kriteria dari alternatif tersebut. Dalam menentukan kriteria penulis melakukan survey kepada mahasiswa sistem informasi Universitas Tanjungpura. Dari pilihan responden, penulis mengambil 5 kriteria terbanyak yang dipilih responden. Kriteria tersebut adalah harga, keiritan, kelangkaan, kualitas dan antrian.

\subsubsection{Penentuan Kriteria}

Dalam melakukan pemecahan masalah sistem pendukung keputusan paling utama ditentukan adalah kriteria. Ada beberapa kriteria dalam yang dibutuhkan dalam pengambilan keputusan pemilihan bahan bakar sepeda motor, antara lain:

a. Kriteria Harga

Dalam pembelian bahan bakar hal yang biasanya jadi pertimbangan adalah harga untuk menentukan seorang pembeli akan membeli bahan bakar tersebut.

Tabel 1. Kriteria harga

\begin{tabular}{ccc}
\hline Kriteria & Sub-Kriteria & Nilai Kriteria \\
\hline Harga & Rp 9200 - Rp 11000 & 1 \\
& Rp 7850-Rp 10000 & 2 \\
& Rp 7850-Rp 10000 & 3 \\
\hline
\end{tabular}

b. Kriteria Keiritan

Dalam pembelian bahan bakar keiritan suatu bahan bakar biasanya jadi pertimbangan untuk menentukan seorang pembeli akan membeli bahan bakar tersebut.

Tabel 2. Kriteria keiritan

\begin{tabular}{ccc}
\hline Kriteria & Sub-Kriteria & Nilai Kriteria \\
\hline Keiritan & Boros & 1 \\
& Sedang & 2 \\
& Irit & 3 \\
\hline
\end{tabular}

c. Kriteria Kelangkaan

Dalam pembelian bahan bakar mudah atau langkanya bahan bakar biasanya menjadi pertimbangan karena jika langka akan susah mencarinya bahkan dapat jauh dari tempat tinggal dan yang lainnya.

Tabel 3. Kriteria kelangkaan

\begin{tabular}{ccc}
\hline Kriteria & Sub-Kriteria & Nilai Kriteria \\
\hline Kelangkaan & Sulit Ditemukan & 1 \\
& Cukup Mudah & 2 \\
& Mudah Ditemukan & 3 \\
\hline
\end{tabular}

d. Kriteria Kualitas

Dalam pembelian bahan bakar kualitas akan menjadi pertimbangan dalam menentukan seorang pembeli akan membeli bahan bakar tersebut.

Tabel 4. Kriteria kualitas

\begin{tabular}{ccc}
\hline Kriteria & Sub-Kriteria & Nilai Kriteria \\
\hline Kualitas & Cukup & 1 \\
& Baik & 2 \\
& Sangat Baik & 3 \\
\hline
\end{tabular}

e. Kriteria Antrian

Dalam pembelian bahan bakar antrian yang panjang ataupun yang pendek biasanya jadi pertimbangan, semakin panjang maka semakin tidak menjadi pilihan seorang pembeli.

Tabel 5. Kriteria antrian

\begin{tabular}{ccc}
\hline Kriteria & Sub-Kriteria & Nilai Kriteria \\
\hline Antrian & Antrian Panjang & 1 \\
& Antrian Pendek & 2 \\
\hline
\end{tabular}


Dalam pengambilan keputusan memerlukan jenis kriteria dan bobot kriteria untuk dapat mengetahui kriteria mana yang diutamakan oleh seorang pengambil keputusan. Jenis kriteria digunakan untuk menentukan apakah kriteria termasuk kedalam "cost" atau "benefit". Cost adalah semakin kecil maka nilai semakin bagus, sedangkan benefit adalah semakin besar maka semakin bagus. Penentuan jenis dan bobot ini diambil dari responden dalam survey penulis.

Tabel 6. Jenis dan Bobot Kriteria

\begin{tabular}{ccc}
\hline Kriteria & Jenis Kriteria & Bobot Kriteria \\
\hline Harga & Cost & $10 \%$ \\
Keiritan & Cost & $20 \%$ \\
Kelangkaan & Benefit & $25 \%$ \\
Kualitas & Benefit & $15 \%$ \\
Antrian & Cost & $30 \%$ \\
\hline
\end{tabular}

\subsubsection{Perhitungan Pemilihan Bahan Bakar Sepeda Motor}

a. Pemberian Nilai Alternatif

Untuk menghitung pilihan memerlukan pemberian nilai alternatif. Pemberian sebagai berikut.

Tabel 7. Pemberian Nilai Alternatif

\begin{tabular}{cccccc}
\hline & \multicolumn{5}{c}{ Kriteria } \\
\cline { 2 - 6 } Alternatif & Harga & Keiritan & Kelangkaan & Kualitas & Antrian \\
& C1 & C2 & C3 & C4 & C5 \\
\hline Pertamax & Rp 9200-Rp 11000 & Irit & Mudah Ditemukan & Sangat Baik & Antrian Pendek \\
Pertalite & Rp 7850-Rp 10000 & Sedang & Cukup Mudah & Baik & Antrian Panjang \\
Premium & Rp 6450-Rp 8000 & Boros & Sulit Ditemukan & Cukup & Antrian Panjang \\
\hline
\end{tabular}

Setelah diberikan nilai kemudian di normalisasi dalam bentuk angka sesuai dengan penentuan nilai kriteria.

Tabel 8. Normalisasi Nilai Alternatif

\begin{tabular}{cccccc}
\hline & \multicolumn{4}{c}{ Kriteria } \\
\cline { 2 - 6 } Alternatif & Harga & Keiritan & Kelangkaan & Kualitas & Antrian \\
& C1 & C2 & C3 & C4 & C5 \\
\hline Pertamax & 1 & 3 & 3 & 3 & 2 \\
Pertalite & 2 & 2 & 2 & 2 & 1 \\
Premium & 3 & 1 & 1 & 1 & 1 \\
\hline
\end{tabular}

b. Pembuatan Matriks Keputusan

Pembuatan matriks keputusan untuk memudahkan menghitung pemilihan keputusan.

$\mathbf{R}=\left[\begin{array}{lllll}1 & 3 & 3 & 3 & 2 \\ 2 & 2 & 2 & 2 & 1 \\ 3 & 1 & 1 & 1 & 1\end{array}\right]$

c. Normalisasi Kriteria

Melakukan normalisasi kriteria dengan menggunakan rumus dalam metode SAW

1) Kriteria Harga(Cost)

Melakukan normalisasi pada kriteria harga.

$\mathrm{R}_{11}=\frac{\min (1,2,3)}{1}=\frac{1}{1}=1$

$$
\mathrm{R}_{12}=\frac{\min (1,2,3)}{2}=\frac{1}{2}=0,50
$$$$
\mathrm{R}_{13}=\frac{\min (1,2,3)}{3}=\frac{1}{3}=0,33
$$

2) Kriteria Keiritan(Cost)

Melakukan normalisasi pada kriteria keiritan.

$\mathrm{R}_{21}=\frac{\min (3,2,1)}{3}=\frac{1}{3}=0,33$

$$
\mathrm{R}_{22}=\frac{\min (3,2,1)}{2}=\frac{1}{2}=0,50
$$$$
\mathrm{R}_{23}=\frac{\min (3,2,1)}{1}=\frac{1}{1}=1
$$

3) Kriteria Kelangkaan(Benefit)

Melakukan normalisasi pada kriteria kelangkaan.

$\mathrm{R}_{31}=\frac{3}{\max (3,2,1)}=\frac{3}{3}=1$

$$
\mathrm{R}_{32}=\frac{2}{\max (3,2,1)}=\frac{2}{3}=0,67
$$$$
\mathrm{R}_{33}=\frac{1}{\max (3,2,1)}=\frac{1}{3}=0,33
$$

4) Kriteria Kualitas(Benefit)

Melakukan normalisasi pada kriteria kualitas 
$\mathrm{R}_{41}=\frac{3}{\max (3,2,1)}=\frac{3}{3}=1$

$\mathrm{R}_{42}=\frac{2}{\max (3,2,1)}=\frac{2}{3}=0,67$

$\mathrm{R}_{43}=\frac{1}{\max (3,2,1)}=\frac{1}{3}=0,33$

5) Kriteria Antrian(Cost)

Melakukan normalisasi pada kriteria antrian.

$\mathrm{R}_{51}=\frac{\min (2,11)}{2}=\frac{1}{2}=0,50$

$$
\mathrm{R}_{52}=\frac{\min (2,1,1)}{1}=\frac{1}{1}=1
$$

$\mathrm{R}_{53}=\frac{\min (2,1,1)}{1}=\frac{1}{1}=1$

d. Melakukan Perankingan

Melakukan perankingan untuk mengetahui hasil akhir dari pemilihan alternatif keputusan.

$\mathrm{V}_{11}=(1)(10)+(0,33)(20)+(1)(25)+(1)(15)+(0,50)(30)=0,716$

$\mathrm{V}_{12}=(0,50)(10)+(0,50)(20)+(0,67)(25)+(0,67)(15)+(1)(30)=0,718$

$\mathrm{V}_{13}=(0,33)(10)+(1)(20)+(0,33)(25)+(0,33)(15)+(1)(30)=0,665$

e. Hasil Perankingan

Ini merupakan hasil perankingan yang telah dihitung sebelumnya.

Tabel 9. Hasil Perankingan

\begin{tabular}{cccc}
\hline No. & Alternatif & Nilai & Ranking \\
\hline 1 & Pertamax & 0,716 & Ranking 2 \\
2 & Pertalite & 0,718 & Ranking 1 \\
3 & Premium & 0,665 & Ranking 3 \\
\hline
\end{tabular}

\subsection{Perancangan Sistem}

Dalam membuat sistem pendukung keputusan penulis melakukan perancangan sistem dengan desain baru. Desain tersebut menjadi tampilan fisik yang dapat dilihat atau dinikmati langsung oleh pengguna.

\subsubsection{Diagram Perancangan}

a. Use Case Diagram

Use case diagram merupakan diagram yang menggambarkan hubungan antara aktor dengan sistem. Use case diagram bisa mendeskripsikan sebuah interaksi antara satu atau lebih aktor dengan sistem yang akan dibuat. Use case diagram juga bisa digunakan untuk mengetahui fungsi apa saja yang ada di dalam sebuah sistem dan bisa juga mempresentasikan sebuah interaksi aktor dengan sistem[16].

1. Use Case Diagram Admin

Pada Use case diagram admin, admin dapat harus melakukan register terlebih dahulu untuk memasuki sistem dan sistem secara otomatis akan mengetahui bahwa aktor berlevel admin. Kemudian setelah register admin harus login untuk memasuki sistem dan semua yang ada pada sistem dapat dijalankan ketika sudah login. Terdapat halaman beranda pada sistem yang berisi apa itu sistem pendukung keputusan dan apa saja fungsi admin sistem. Kemudian terdapat halaman data pengguna untuk mengeola data pengguna yang masuk sistem.

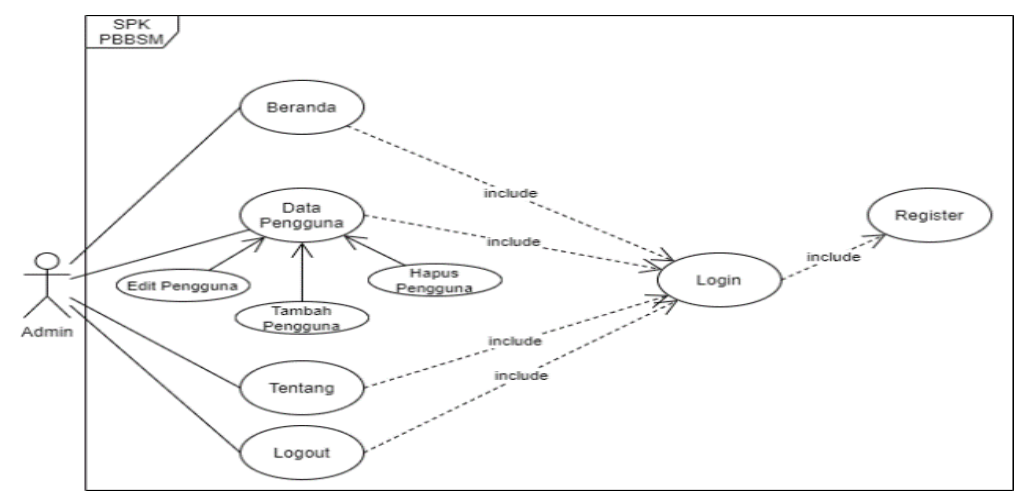

Gambar 2. Use case diagram Admin

2. Use Case Diagram User

Pada Use case diagram user atau pengguna, pengguna harus melakukan register terlebih dahulu untuk memasuki sistem Kemudian setelah register admin harus login untuk memasuki sistem dan semua yang ada pada sistem dapat dijalankan ketika sudah login. Terdapat halaman beranda yang dapat digunakan untuk memasukkan form kriteria yang kemudian keluar hasil ketika di submit, kemudian dapat melihan transaksi perhitungan pada sistem, transaksi akan ada ketika sudah mengisi form kriteria. 


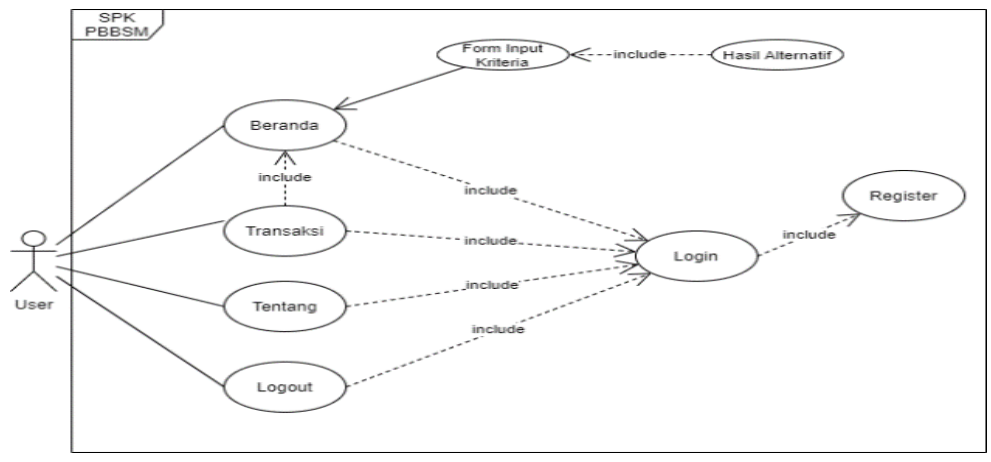

Gambar 3. Use case diagram User

\subsection{Implementasi Program}

\section{a. Tampilan Halaman Login}

Halaman login dibuat untuk memberi fasilitas pada pengguna aplikasi untuk masuk dan menggunakan sistem ini. Berikut adalah tampilan untuk masuk ke sistem.

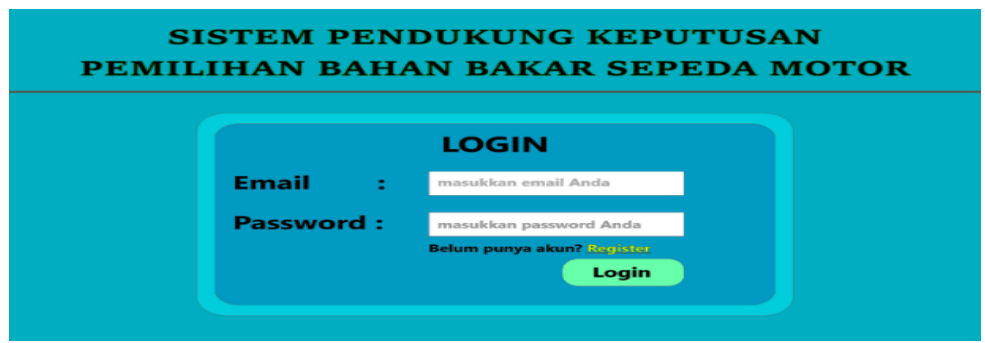

\section{b. Tampilan Halaman Register}

Gambar 4. Tampilan Login

Halaman register dibuat untuk memberi fasilitas pada pengguna aplikasi mendaftar dan masuk untuk menggunakan sistem ini. Berikut adalah tampilan register ke sistem.

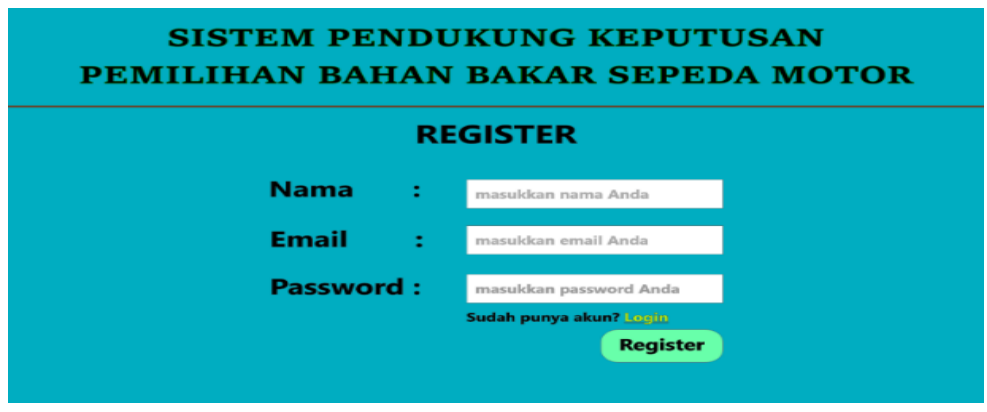

\section{c. Beranda Administator}

Gambar 5. Tampilan Register

Halaman ini ditujukan untuk pengguna level administrator yang didalamnya ada link menu utama yaitu, beranda, transaksi, tentang, logout, berikut adalah tampilanya.

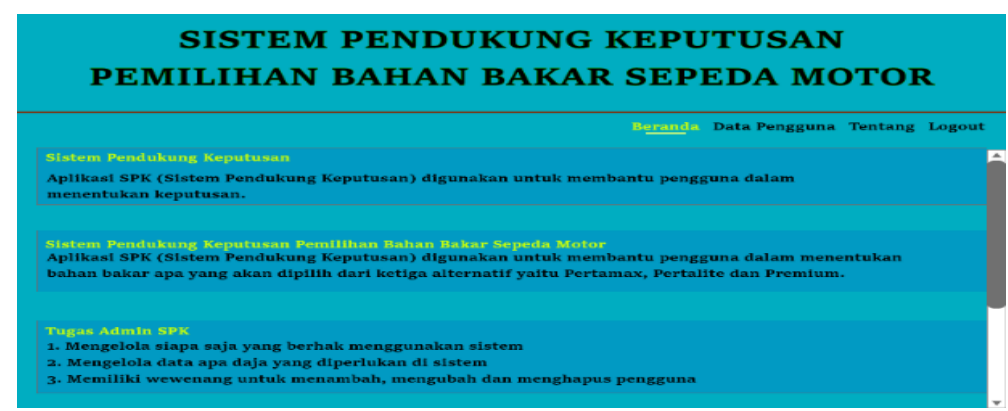

Gambar 6. Beranda Administator

\section{d. Kelola Data Pengguna}


Halaman ini hanya dapat diakses pengguna berlevel admin. Halaman ini digunakan untuk mengelola data pengguna yang masuk kedalam sistem.

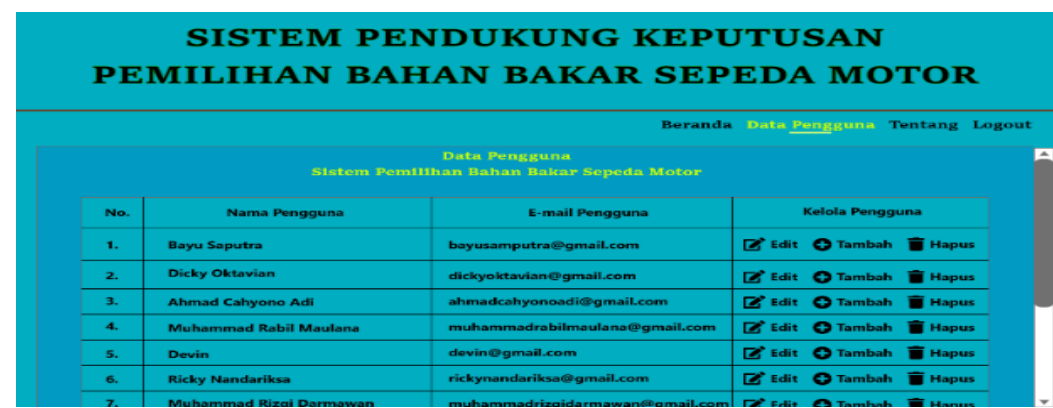

\section{e. Beranda User}

Gambar 7. Kelola Data Pengguna

Halaman ini ditujukan untuk pengguna yang didalamnya ada link menu utama yaitu, beranda, transaksi, tentang, logout, dan berisi form untuk input kriteria yang digunakan untuk mencari alternatif, berikut adalah tampilanya.

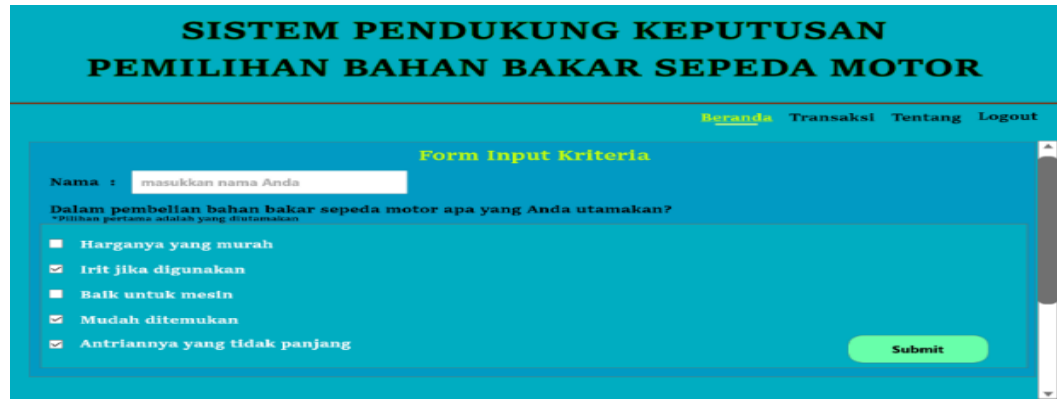

\section{f. Tampilan Hasil Seleksi}

Gambar 8. Beranda User

Halaman ini merupkan hasil dari submit yang dari form kriteria pada halaman beranda dan dapat melihat hasil dari kriteria yang telah diinputkan. Berikut tampilannya.

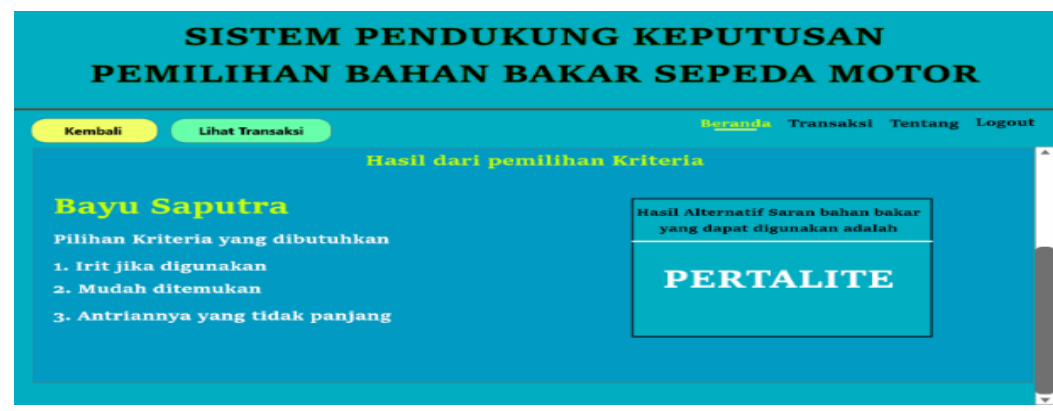

Gambar 9. Tampilan Hasil Seleksi

\section{g. Tampilan Transaksi (Normalisasi Kriteria)}

Halaman ini merupakan tampilan transaksi yang merupakan hasil normalisasi kriteria menggunakan metode SAW. Berikut tampilannya.

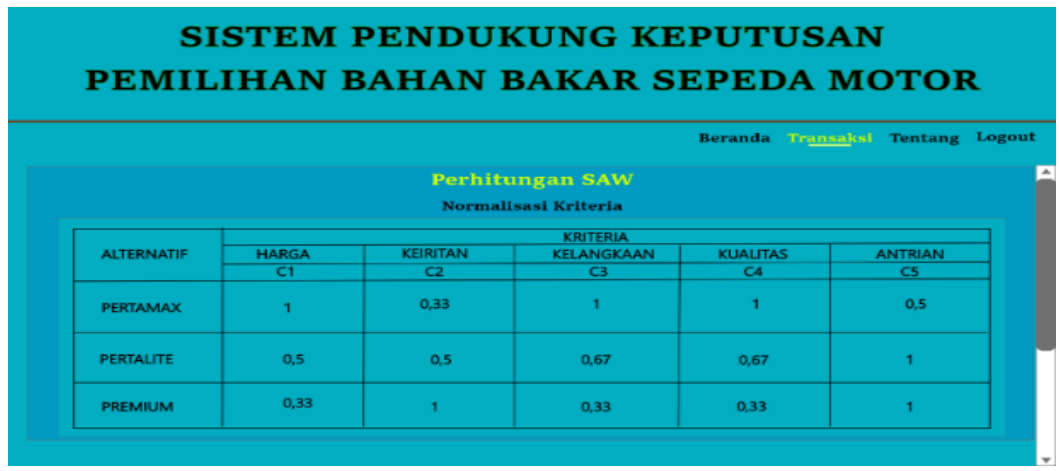

Gambar 10. Tampilan Transaksi (Normalisasi Kriteria) 


\section{h. Tampilan Transaksi (Hasil Perangkingan)}

Halaman ini merupakan tampilan transaksi yang merupakan hasil perankingan dari dikalikan dengan bobot yang diberikan menggunakan metode SAW. Berikut tampilannya.

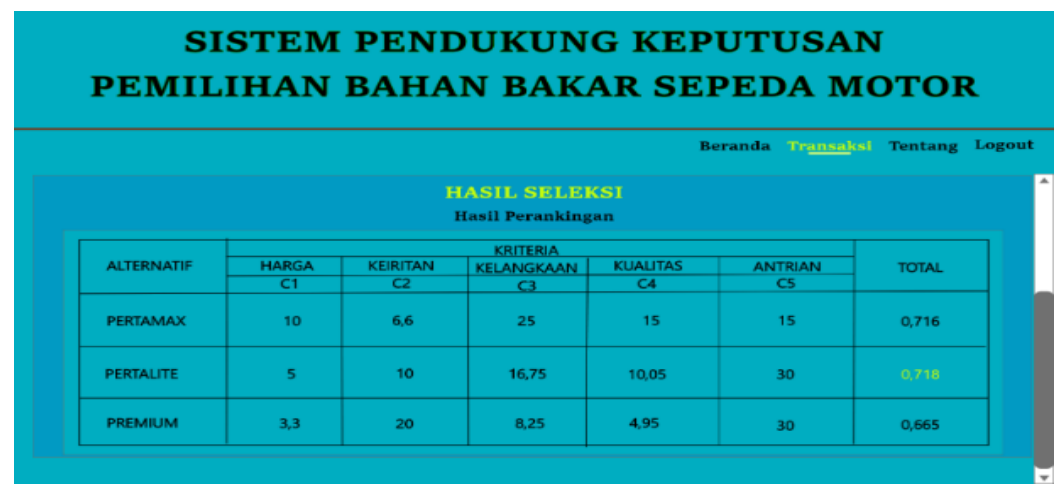

Gambar 11. Tampilan Transaksi (Hasil Perangkingan)

\section{KESIMPULAN}

Kesimpulan dari penelitian ini dalam pemilihan bahan bakar kendaraan sepeda motor dapat dilakukan dengan menggunakan sistem pendukung keputusan. Sistem pendukung keputusan ini dibuat dengan metode SAW untuk melakukan perhitungan dan pembobotan kriteria. Hasil dari perhitungan kriteria yang kemudian mendapatkan hasil alternatif pilihan sesuai dengan contoh kasus diatas pertalite mendapatkan nilai perankingan tertinggi dengan nilai 0,716 sehingga menjadi alternatif yang dipilih.

\section{REFERENCES}

[1] A. Muzaki, "Harga BBM: Pertalite, Premium, Pertamax, dan Pertamax Turbo di Semua Provinsi Februari 2021," 2021. .

[2] S. R. Abdul Rojak and A. Rifai, "Penerapan Metode Analytical Hierarchy Process dalam Memilih Bahan Bakar Minyak untuk Kendaraan Roda Dua," J. Kaji. Ilm., vol. 18, no. 1, pp. 1-8, 2018.

[3] U. Kasma, J. S. Informasi, and P. Berbobot, "Sistem Pendukung Keputusan Pembelian Sepeda Motor Menggunakan Metode Simple Additive Weighting (SAW)," e-Jurnal JUSITI (Jurnal Sist. Inf. dan Teknol. Informasi), vol. 7-2, no. 2, pp. 104-115, 2018.

[4] E. I. Putra, "Sistem Pendukung Keputusan Memilih Sepeda Motor Matic Terbaik 'Honda 110cc' Dengan Metode AHP,” Indones. J. Comput. Inf. Technol., vol. 3, no. 2, p. 3(2), 165-169, 2018.

[5] D. Nofriansyah and S. Defit, Multi Criteria Decision Making (MCDM) pada Sistem Pendukung Keputusan. 2018.

[6] T. Limbong, "Implementasi Metode Simple Additive Weighting Untuk," Pengetahuan, J. Ilmu Komputer, D A N Teknol., vol. 3, no. 2, pp. 233-238, 2018.

[7] Asep Syaputra, "Sistem Pendukung Keputusan Penerimaan Beasiswa Kurang Mampu Dengan Metode Simple Additive Weighting (Saw),” J. Ilm. Bin. STMIK Bina Nusant. Jaya Lubuklinggau, vol. 1, no. 2, pp. 50-55, 2019.

[8] F. Frieyadie, "Penerapan Metode Simple Additive Weight (Saw) Dalam Sistem Pendukung Keputusan Promosi Kenaikan Jabatan,” J. Pilar Nusa Mandiri, vol. 12, no. 1, pp. 37-45, 2016.

[9] T. Limbong et al., Sistem Pendukung Keputusan: Metode \& Implementasi. Medan: Yayasan Kita Menulis, 2020.

[10] A. Setiadi, Y. Yunita, and A. R. Ningsih, "Penerapan Metode Simple Additive Weighting(SAW) Untuk Pemilihan Siswa Terbaik," J. Sisfokom (Sistem Inf. dan Komputer), vol. 7, no. 2, p. 104, 2018

[11] I. Judi, T. Situmeang, S. Hummairoh, and S. M. Harahap, "Application of SAW ( Simple Additive Weighting ) for the Selection of Campus Ambassadors,” IJICS (International J. Informatics Comput. Sci., vol. 5, no. 1, pp. 21-28, 2021.

[12] S. H. Sahir, R. Rosmawati, and K. Minan, "Simple Additive Weighting Method to Determining Employee Salary Increase Rate,” Int. J. Sci. Res. Sci. Technol., vol. 3, no. 8, pp. 42-48, 2017.

[13] S. K. Simanullang and A. G. Simorangkir, "Sistem Pendukung Keputusan Penerimaan Calon Karyawan Menggunakan Metode Simple Additive Weighting," TIN Terap. Inform. Nusant., vol. 1, no. 9, pp. 472-478, 2021.

[14] M. R. Ramadhan, M. K. Nizam, and Mesran, "Penerapan Metode SAW (Simple Additive Weighting) Dalam Pemilihan Siswa-Siswi Berprestasi Pada Sekolah SMK Swasta Mustafa," TIN Terap. Inform. Nusant., vol. 1, no. 9, pp. 459-471, 2021. 
[15] E. Ridhawati, G. r K. Sirega, and D. Iriawan, "Metode Simple Additive Weighting (Saw) Pada Sistem Pendukung Keputusan Penilai Kinerja Guru (Pkg) (Studi Kasus Smp 171 Pagelaran)," J. Inf. dan Komput., vol. 6 , no. 2, pp. 38-49, 2018.

[16] M. K. Hutauruk, "UML Diagram : Use Case Diagram," 2019. . 